\title{
THREE SPECIES OF SARGASSUM (PHAEOPHYCEAE) WITH COMPRESSED PRIMARY BRANCHES IN THE GULF OF THAILAND
}

\author{
Thidarat Noiraksar, Tetsuro Ajisaka and Hisao Ogawa \\ ${ }^{1}$ Institute of Marine Science, Burapha University, Bangsaen, Chon Buri 20131, Thailand \\ "e-mail: sargassum2005@yahoo.com \\ ${ }^{2}$ Graduate School of Agriculture, Kyoto University, Kyoto 606-8502, Japan \\ ${ }^{3}$ School of Fisheries Science, Kitasato University, Iwate 022-0101, Japan
}

\begin{abstract}
Three species of Sargassum with compressed primary branches, S. binderi Sonder, S. oligocystum Montagne and $S$. swartzii (Turner) C.A. Agardh, have been described from the Gulf of Thailand. S. swartzii is the first record of this species from the coast of Thailand. A key for these three species and for each species descriptions have been completed. The clear distinction among these three species is clearly shown and discussed. S. binderi has slender lanceolate leaves, a dentate margin along the compressed stem of its vesicles, and clear spines along the whole margin of the flattened receptacles. S. oligocystum has broader lanceolate leaves with an acute to rounded apex, almost entire, spherical vesicles, and only few spines on the margin of the slightly compressed receptacles. S. swartzii has linear lanceolate leaves, pointed or crowned vesicles, and few spines near the tip of its almost terete receptacles.
\end{abstract}

Keywords: Phaeophyceae, Sargassum binderi, S. oligocystum, S. swartzii, the Gulf of Thailand

\section{INTRODUCTION}

Sargassum C. Agardh (Sargassaceae, Fucales), a very large brown seaweed genus including nearly 400 species, is widely distributed in warm and temperate waters, especially in the Indo-west Pacific region and Australia (Tseng et al., 1985). Thailand is a tropical country in southeast Asia with a coastline of approximately 2,650 kilometers, consisting of 1,880 kilometers along the Gulf of Thailand (Pacific Ocean) and 770 kilometers along the Andaman Sea (Indian Ocean); both coasts have a diverse seaweed flora. Thai species of Sargassum were first reported by Reinbold in the "Flora of Koh Chang" from the specimens collected by Schmidt during the Danish Expedition to Siam 1899-1900. S. polycystum C.A. Agardh was reported from Koh Kahdat, Trat Province situated on the east coast of the Gulf of Thailand (Schmidt, 1900-1916). Lewmanomont (1988) reported $S$. polycystum from coral reefs along the Gulf of Thailand, and S. crassifolium
J.G. Agardh and S. polycystum from the Andaman Sea. Egerod (1974) collected S. grevillei J.G. Agardh on the Fifth Thai-Danish Expedition of 1966 from Koh Ra, Ranong Province, the Andaman Sea (this species may be a misidentification of $S$. stolonifolium Phang et Yoshida [Ajisaka and Lewmanomont (2004)]. Nateewathana et al., (1981) and Aungtonya and Liao (2002) compiled and updated the extensive checklist, adding $S$. crassifolium, $S$. granuliferum C.A. Agardh and S. siliquosum J.G. Agardh from the Reference Collection of the Phuket Marine Biological Center (PMBC). Ajisaka and Lewmanomont (2004) reported $S$. stolonifolium Phang et Yoshida from the Andaman Sea.

In this paper, we describe three Sargassum species with compressed primary branches, $S$. binderi Sonder, $S$. oligocystum Montagne and $S$. swartzii (Turner) C.A. Agardh and discuss on the clearly distinguishable characters among these species. 


\section{MATERIALS AND METHODS}

The specimens were collected from nine provinces along the Gulf of Thailand: Chon Buri, Rayong, Chanthaburi, Trat (the east coast); Prachuap Khirikhan, Chumphon, Surat Thani, Nakhon Si Thammarat and Songkhla (the west coast) (Fig. 1) from 2001-2006. Whole thalli (with holdfasts) were collected during low tide. Specimens from the deeper areas were collected by SCUBA diving. Some of the collected specimens were fixed in $4 \%$ formaldehydeseawater, and the remainder were dried on herbarium sheets. Important morphological characters of the thallus were drawn and sections of receptacles have been prepared and stained with $1 \%$ aniline blue intensified with $1 \% \mathrm{HCl}$ and mounted on glass slides using $50 \%$ glucose syrup (Karo Syrup, Corn Products). The specimens from this study are deposited at the Bangsaen Institute of Marine Science (BIMS), Burapha University and Kasetsart University Museum of Fisheries (KUMF)

\section{RESULTS}

Key to Sargassum species with compressed primary branches

1. Receptacle flattened or slightly compressed..2

1. Receptacle terete S. swartzii

2. Sharp spines along the whole margin of each receptacle S. binderi

2. Only a few spines on the margin of each receptacle. S. oligocystum

\section{Description of The Species}

Sargassum binderi Sonder in J.G. Agardh, 1848, p. 328 (Fig. 2)

J.G. Agardh, 1889, p. 87, Figs. 26-2; Yamada, 1925, p. 245; Chou and Chiang, 1981, p. 143; Yoshida, 1988, p.10; Trono, 1992, p. 46, Figs. 1-4, 109; 1997, p. 128, Fig. 86; Tseng and Lu, 1995b, p. 96, Fig. 9; Ajisaka et al., 1999, p. 28, Fig. 3

Holdfast discoid, up to $12 \mathrm{~mm}$ in diameter. Stem terete, smooth to warty, up to $3 \mathrm{~mm}$ in

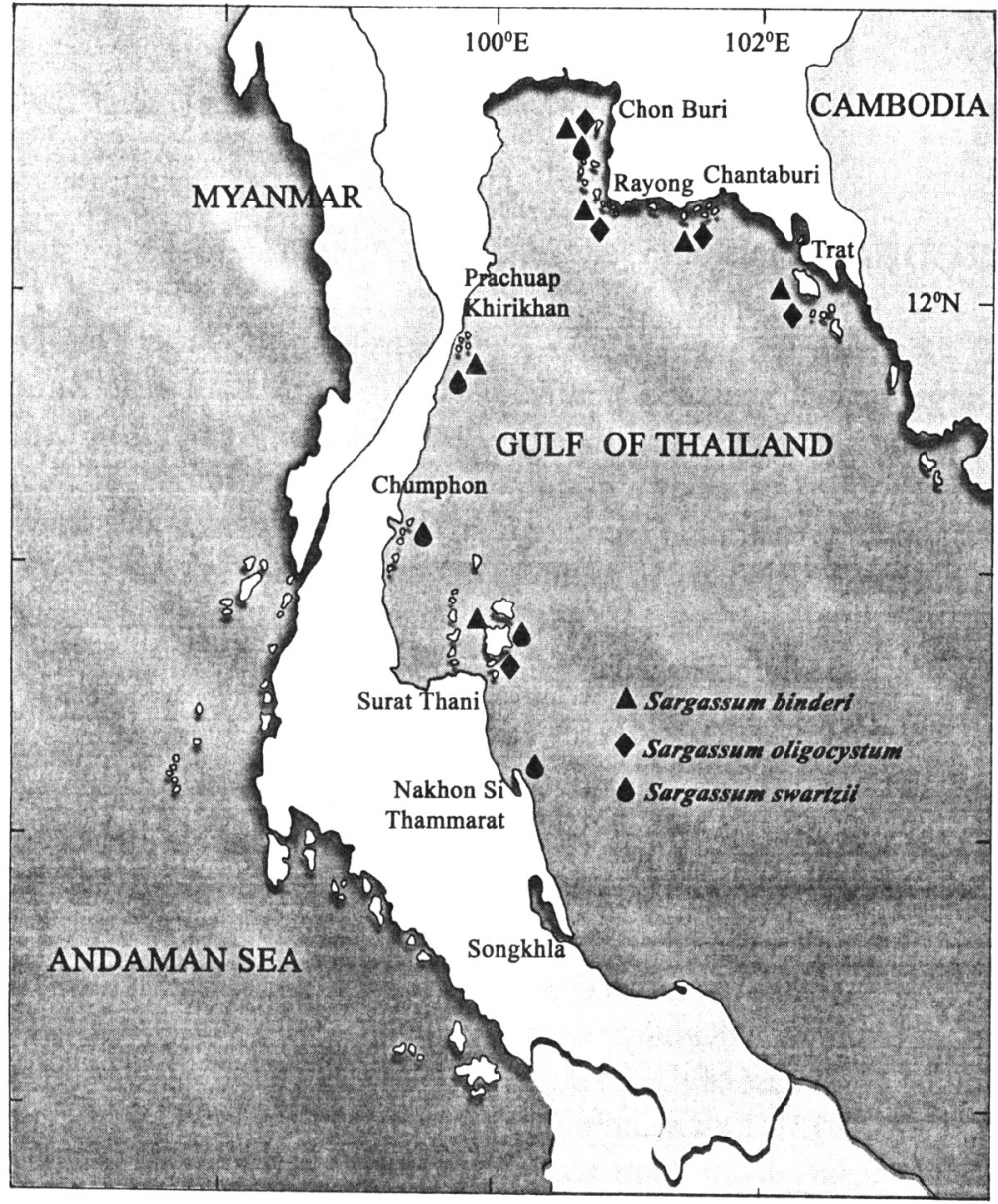

Figure 1. Study area and distribution of collecting sites along the Gulf of Thailand 

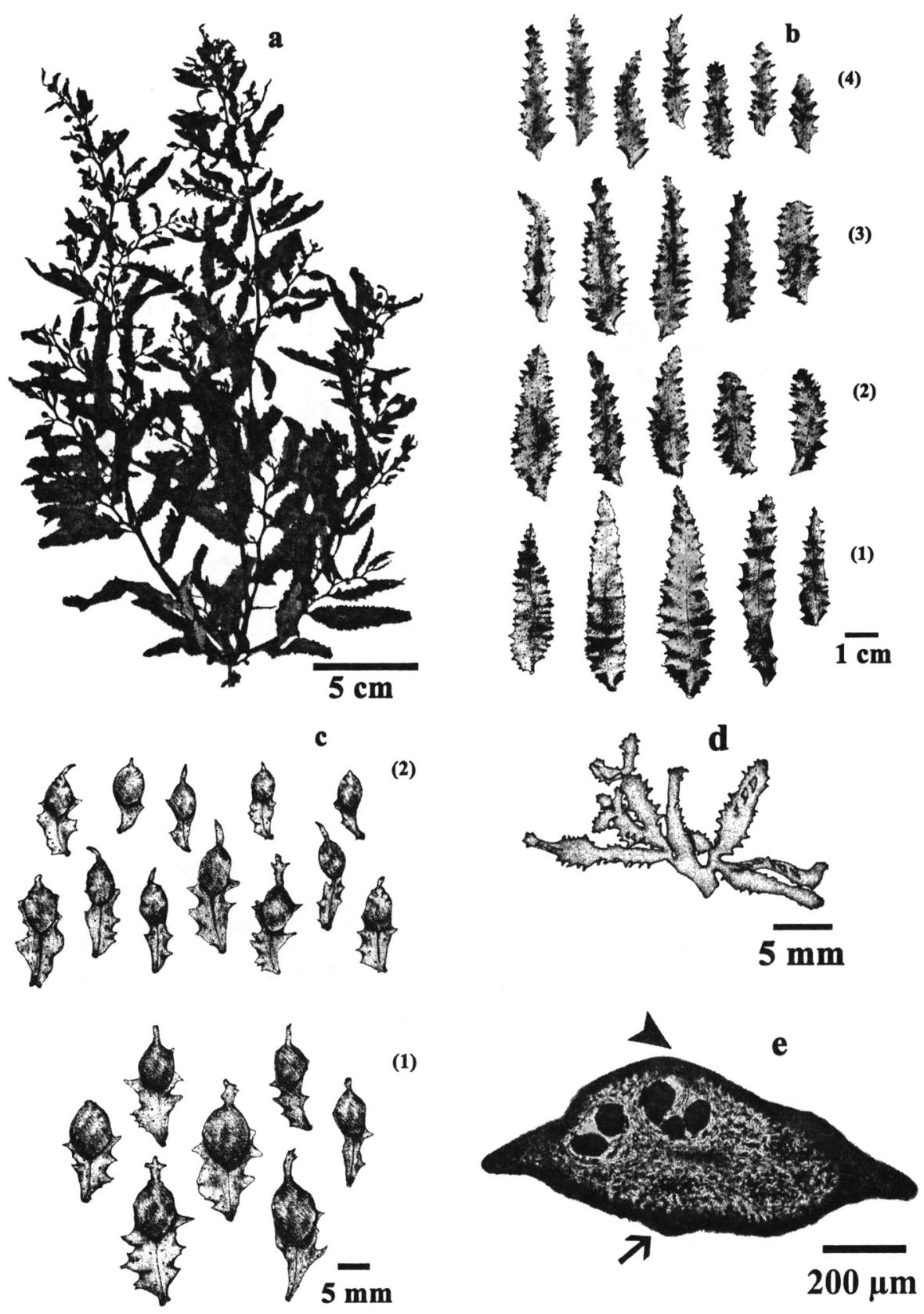

Figure 2. Sargassum binderi Sonder. a. Habit, b. Leaves: (1) primary leaves in lower parts, (2) primary leaves in upper parts, (3) secondary leaves in lower parts, (4) secondary leaves in upper parts, c. Vesicles: (1) primary branches, (2) secondary branches, d. Androgynous receptacles, e. Transverse section of receptacle showing male conceptacles (arrow) and female conceptacles (arrowhead).

diameter, about $1 \mathrm{~cm}$ long, producing 6-8 spirally arranged primary branches. Primary branches flattened to compressed, smooth, up to $46 \mathrm{~cm}$ long, and up to $5 \mathrm{~mm}$ wide. Secondary branches distichously arranged, slightly compressed, smooth, up to $40 \mathrm{~cm}$ long, branching interval of up to $4 \mathrm{~cm}$. Lower leaves slender lanceolate, simple, with asymmetrical base, up to $8 \mathrm{~cm}$ long, and up to 16 mm wide, with acute to round apex, margin entire to dentate with sharp teeth, midrib distinct near apex, small cryptostomata scattered; upper leaves slender lanceolate, simple, with asymmetrical to cuneate base, up to $7 \mathrm{~cm}$ long, and up to $11 \mathrm{~mm}$ wide, with acute to round apex, margin dentate with small teeth, midrib vanishing near apex, small and cryptostomata scattered. Vesicles spherical 

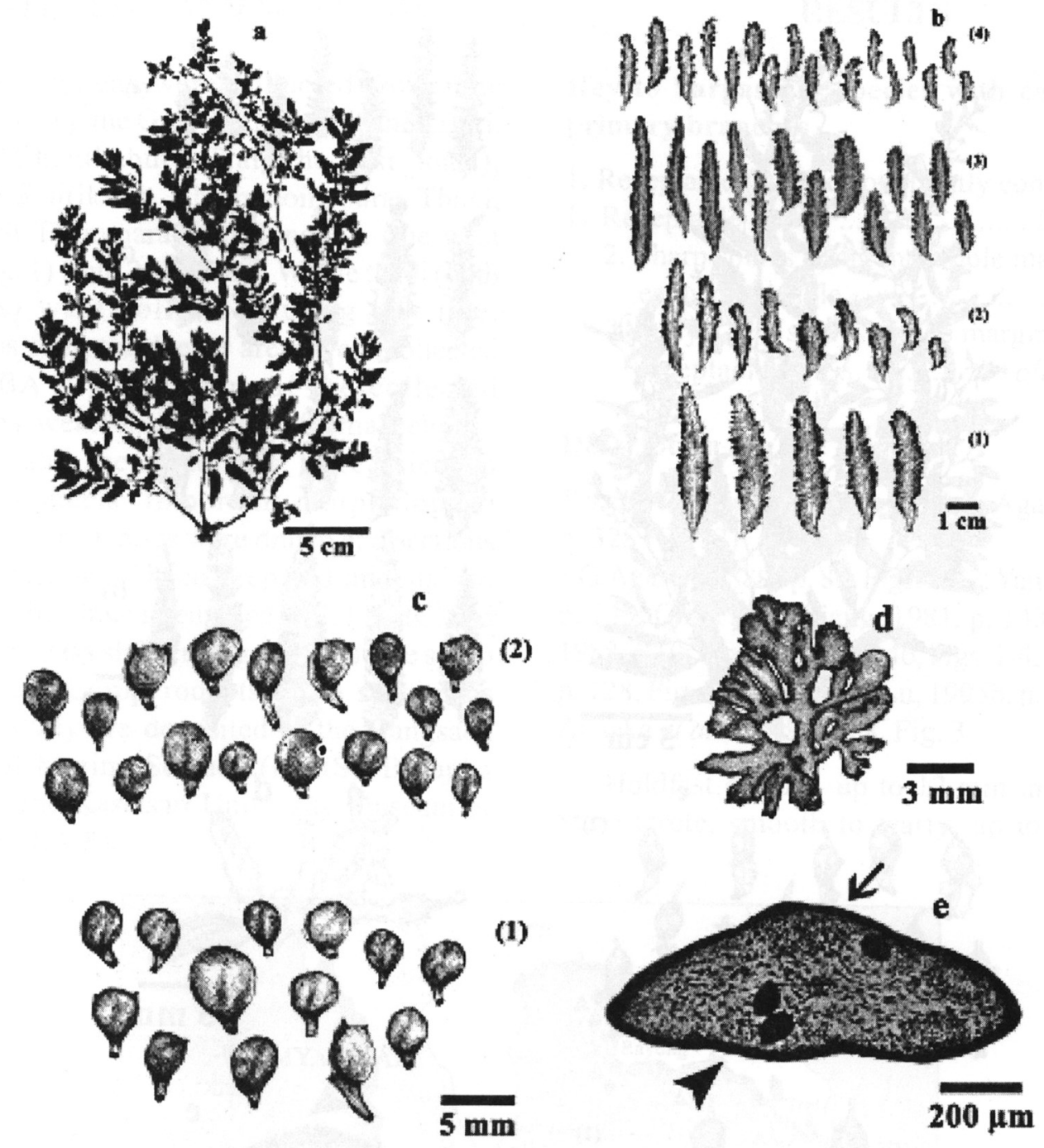

Figure 3. Sargassum oligocystum Montagne. a. Habit, b. Leaves: (1) primary leaves in lower parts, (2) primary leaves in upper parts, (3) secondary leaves in lower parts, (4) secondary leaves in upper parts, c. Vesicles: (1) primary branches, (2) secondary branches, d. Androgynous receptacles, e. Transverse section of receptacle showing male conceptacles (arrow) and female conceptacles (arrowhead).

to elliptical, up to $10 \mathrm{~mm}$ long, up to $6 \mathrm{~mm}$ wide, and up to $5 \mathrm{~mm}$ thick, often mucronate at the margin and pointed, occasionally entire, stalk flattened, with dentate margin, usually as long as the vesicle or longer than the vesicle.

Plants monoecious. Receptacles androgynous, flattened, often twisted, up to $18 \mathrm{~mm}$ long, up to 2 $\mathrm{mm}$ wide, sharply dentate along the whole margin, simple to furcate, racemosely arranged.

Habitat: Growing on rocks and dead corals of intertidal to subtidal areas.

Distribution: Trat Province: Chang Islands and Kut Island. Chantaburi Province: Khung Kraban. Rayong Province: Suan Son, Man Nai Island and
Saket Island. Chon Buri Province: Nang Rong Beach, Samae San Island and Kham Island. Prachuap Khirikhan Province: Thong Lang Beach. Surat Thani Province: Samui Island.

Sargassum oligocystum Montagne, Voy. Pot. Sud. Bot. 1:67, 1845. (Fig. 3)

Reinbold, 1913, p. 156; Grunow, 1915, p. 383; Pham, 1967, p. 295; Tseng, 1983, p. 234, pl. 118, Fig. 1; Noro et al., 1994, p. 27, Fig 3; Tseng and Lu, 1995b, p. 100, Fig. 10; Lewmanomont and Ogawa, 1995, p. 83; Ajisaka et al., 1999, p. 34, Fig. 8 
Holdfast discoid, up to $12 \mathrm{~mm}$ in diameter. Stem terete, smooth, up to $4 \mathrm{~mm}$ in diameter, about $12 \mathrm{~mm}$ long, producing 6-8 spirally arranged primary branches. Primary branches flattened to compressed, smooth, up to $49 \mathrm{~cm}$ long, and up to 4 $\mathrm{mm}$ wide. Secondary branches distichously arranged, terete to slightly compressed, smooth, up to $19 \mathrm{~cm}$ long, branching interval of up to $5 \mathrm{~cm}$. Lower leaves broad lanceolate to spatulate, with simple, asymmetrical base, up to $6 \mathrm{~cm}$ long, and up to $18 \mathrm{~mm}$ wide, with round apex, margin entire to dentate with small teeth, midribs distinct, vanishing near apex, small cryptostomata scattered; upper leaves lanceolate to spatulate, with simple, asymmetrical base, up to $4 \mathrm{~cm}$ long, and up to $19 \mathrm{~mm}$ wide, with rounded apex, margin entire to dentate with small teeth, midrib vanishing near apex, small cryptostomata scattered. Vesicles spherical to elliptical, up to $4 \mathrm{~mm}$ long, up to $4 \mathrm{~mm}$ wide, and up to $3 \mathrm{~mm}$ thick, usually entire at the apex, seldomly with small appendages, stalk terete, usually much shorter than the vesicle.

Plants monoecious. Receptacles androgynous, slightly compressed, up to $9 \mathrm{~mm}$ long, up to $3 \mathrm{~mm}$ wide, warty or with few spines on the margin, simple to furcated twice or three times, racemosely arranged.

Habitat: Growing on rocks and dead corals of reef flats to subtidal areas.

Distribution: Trat Province: Kut Island. Chantaburi Province: Khung Kraban and Khung Wiman. Rayong Province: Man Nai Island and Samet Island. Chon Buri Province: Nang Rong Beach and Samae San Island. Surat Thani Province: Samui Island.

Sargassum swartzii (Turner) C.A. Agardh, Sp. Algarum, vol.1, 11, 1820. (Fig.4)

Basionym: Fucus swartzii Turner, Fuci, vol. 4, pl. 248, 1819.

C.A. Agardh, 1824, p. 296; J.G. Agardh, 1848, p. $328 ; 1889$, p. 85, pl. 26.1; Reinbold, 1913, p. 157; Grunow, 1915, p. 381; Setchell, 1935, p. 3, pl. 1; Yamada, 1942, p. 25, fig. 1; Pham, 1967, p. 293, Fig. 13; Tseng, 1983, p. 238, pl. 120, Fig. 1; Noro et al., 1994, p. 27, Figs. 4, 9; Tseng and Lu, 1995a, p. 79, Fig. 10; Ajisaka, 2002, p. 82, Figs. 12-15

Holdfast discoid, up to $17 \mathrm{~mm}$ in diameter. Stem terete, smooth, up to $4 \mathrm{~mm}$ in diameter, about $7 \mathrm{~mm}$ long, producing $4-8$ spirally arranged primary branches. Primary branches compressed, smooth, up to $140 \mathrm{~cm}$ long, and up to $6 \mathrm{~mm}$ wide. Secondary branches distichously arranged, compressed, smooth, up to $63 \mathrm{~cm}$ long, branching interval of up to $8 \mathrm{~cm}$. Lower leaves elongate to linear lanceolate, simple, with asymmetrical base, up to $8 \mathrm{~cm}$ long, and up to $11 \mathrm{~mm}$ wide, usually with acute apex, margin dentate, midrib distinct near apex, small cryptostomata scattered; upper leaves linear lanceolate, simple, with asymmetrical base, up to $6 \mathrm{~cm}$ long, and up to $6 \mathrm{~mm}$ wide, with acute apex, margin dentate with small teeth, midrib vanishing near apex, small cryptostomata arranged in one row. Vesicles usually elliptical, simple, up to 10 $\mathrm{mm}$ long, up to $6 \mathrm{~mm}$ wide, and up to $5 \mathrm{~mm}$ thick, usually pointed or occasionally with a short crown leaf, margins entire, stalk terete to slightly compressed or cuneate (terete at the lower part and compressed at the upper part), usually as long as the vesicles, occasionally longer than the vesicles.

Plants monoecious. Receptacles terete, occasionally slightly compressed, up to $16 \mathrm{~mm}$ long, and up to $2 \mathrm{~mm}$ wide, simple to furcated two-five times, bearing few spines near the apex, arranged in a cyme to compound cyme, pseudozygocarpic with a vesicle.

Habitat: Growing on rocks and dead corals of intertidal to subtidal areas.

Distribution: Chon Buri Province: Nang Rong Beach. Prachuap Khirikhan Province: Thong Lang Beach. Chumphon Province: Ban Bang Jak and Ban San Siam. Surat Thani Province: Samui Island. Nakhon Si Thammarat Province: Hin Ngam Beach.

\section{DISCUSSION}

Sargassum binderi, $S$. oligocystum and $S$. swartzii are often confused at the South-East Asian coasts because they have compressed primary branches and monoecious (androgynous) receptacles. Morphological characters were compared for these three species in Thailand (Table 1).

Sargassum binderi has been characterized by the receptacles with sharply spinous margin in the original description (J.G. Agardh, 1848) and this was recognized in the descriptions of Chinese specimens (Tseng and Lu, 1995b). Womersley and Bailey (1970) suggested that $S$. binderi was a synonym of $S$. oligocystum. However, we retain $S$. binderi on the basis of its character receptacles with a clear spinous margin. S. oligocystum has 

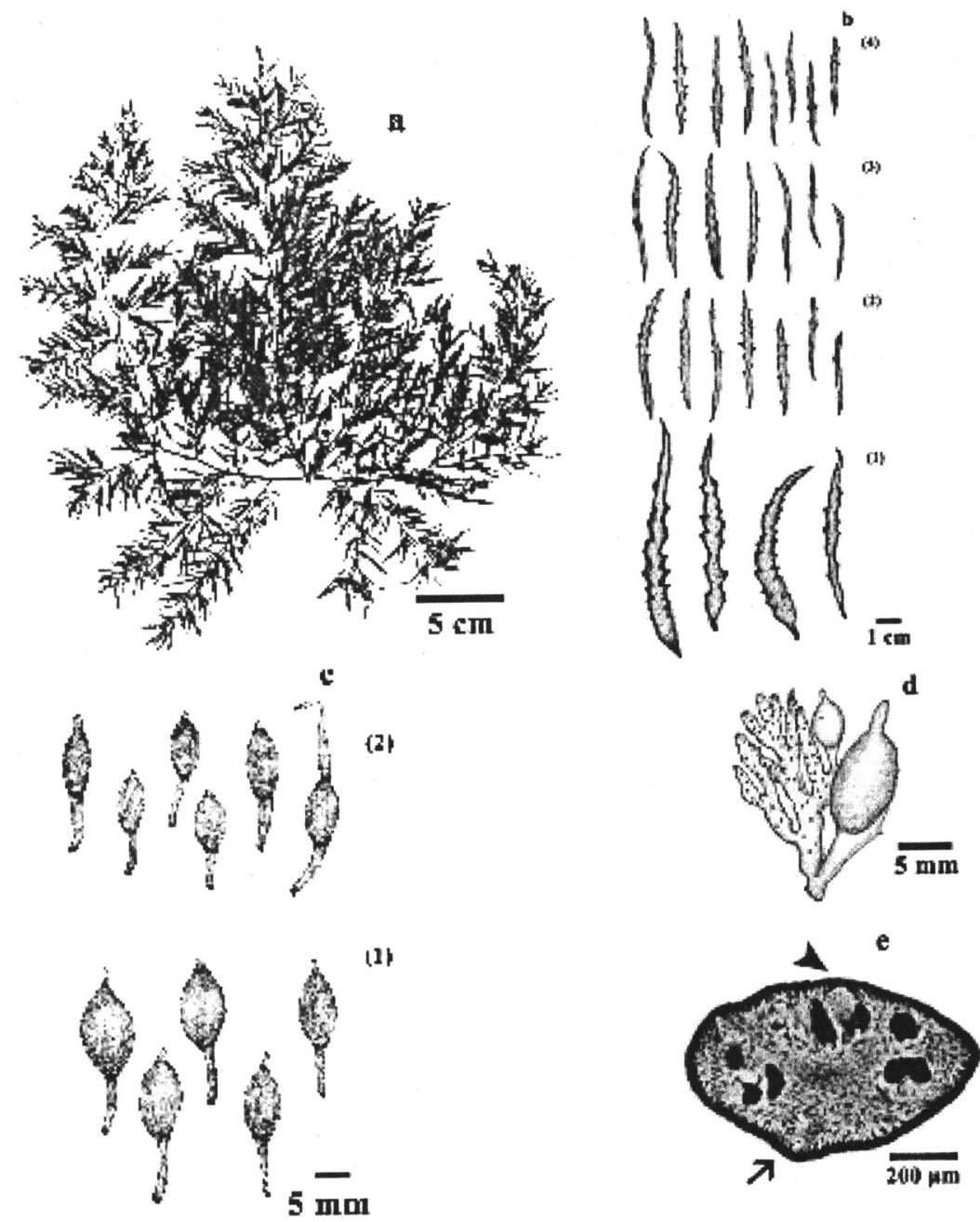

Figure 4. Sargassum swartzii (Turner) C.A. Agardh. a. Habit, b. Leaves: (1) primary leaves in lower parts, (2) primary leaves in upper parts, (3) secondary leaves in lower parts, (4) secondary leaves in upper parts, c. Vesicles: (1) primary branches, (2) secondary branches, d. Androgynous receptacles, e. Transverse section of receptacle showing male conceptacles (arrow) and female conceptacles (arrowhead).

receptacles with only apical spines (Noro et al., 1994). S. binderi from Thailand closely resembles to the specimens reported from China and Malaysia (Tseng and Lu, 1995b; Ajisaka et al., 1999) in the morphology of its vesicles and receptacles. These vesicles are spherical to elliptical, often mucronate and pointed at their apex, occasionally entire. The stalk of the vesicle is flattened, has a clear dentate margin and is usually as long as the vesicle or longer than the vesicle. Receptacles are monoecious, flattened, twisted and having sharply spinous margin. Noro et al., (1994) reported this species is "mostly monoecious or rarely dioecious", however we observed only monoecious in our materials.
Sargassum oligocystum from Thailand closely resembles the specimens from Malaysia (Ajisaka et al., 1999) and Japan (Ajisaka et al., 1995) in the morphology of their compressed primary branches; spherical to elliptical vesicles with entire apex, occasionally with small appendages on one side or both sides, and terete stalks which are shorter than the vesicles; receptacles slightly compressed, warty or with few spines on the margin, and pseudozygocarpic. However, our specimens (monoecious) differ from those of China (Tseng and Lu, 1995b) and the Philippines (Trono, 1992) which are dioecious. Noro et al., (1994) reported that $S$. oligocystum has receptacles with apical spines. Tseng (1983) 
Table 1. Comparison of three species of Sargassum with compressed primary branches in the Gulf of Thailand.

\begin{tabular}{|l|l|l|l|}
\hline \multicolumn{1}{|c|}{ Characters } & \multicolumn{1}{c|}{ S. binderi } & \multicolumn{1}{c|}{ S. oligocystum } & \multicolumn{1}{c|}{ S. swartzii } \\
\hline Primary branch & compressed & compressed & compressed \\
\hline length(max) & $46 \mathrm{~cm}$ & $49 \mathrm{~cm}$ & $140 \mathrm{~cm}$ \\
\hline width(max) & $5 \mathrm{~mm}$ & $4 \mathrm{~mm}$ & $6 \mathrm{~mm}$ \\
\hline Leaves & & & \\
\hline morphology & slender lanceolate & broad lanceolate & linear lanceolate \\
\hline apex & acute to rounded & rounded & acute \\
\hline length (max) & $8 \mathrm{~cm}$ & $6 \mathrm{~cm}$ & $8 \mathrm{~cm}$ \\
\hline width (max) & $16 \mathrm{~mm}$ & $18 \mathrm{~mm}$ & $11 \mathrm{~mm}$ \\
\hline Vesicles & & & \\
\hline morphology & spherical to elliptical & spherical to elliptical & elliptical \\
\hline length(max) & $10 \mathrm{~mm}$ & $4 \mathrm{~mm}$ & $10 \mathrm{~mm}$ \\
\hline width(max) & $6 \mathrm{~mm}$ & $4 \mathrm{~mm}$ & $6 \mathrm{~mm}$ \\
\hline depth(max) & $5 \mathrm{~mm}$ & $3 \mathrm{~mm}$ & $5 \mathrm{~mm}$ \\
\hline apex & spines, pointed & round, rarely pointed & pointed, crowned \\
\hline stalk & flattened, & $\begin{array}{l}\text { terete, } \\
\text { shorter than vesicle }\end{array}$ & terete to cuneate, \\
same length as vesicle
\end{tabular}

reported in Chinese specimens that the vesicles are ovate or ellipsoidal, often crowned and mucronate at the apices, and borne on subcylindrical stalks, while the receptacles were flattened, forked, with coarsely spinous margins.

Sargassum swartzii has spines only at the tips of receptacles (J.G. Agardh, 1848). However, Noro et al., (1994) reported that $S$. oligocystum has receptacles with apical spines and $S$. swartzii has receptacles without spines. It is very confusing. Tseng and Lu (1995a, 1995b) reported that $S$. swartzii had receptacles with small apical spines, but they did not include any information on receptacles in Chinese specimens of $S$. oligocystum. Thai specimens of $S$. swartzii closely resemble to the specimens from China (Tseng and Lu, 1995a, 1995b) and Malaysia (Ajisaka, 2002) in having lanceolate to linear lanceolate leaves, which are acute at the apex; vesicles elliptical, pointed at the apex, with entire margins, cuneate stalks; receptacles compressed, usually terete or slightly compressed. Thai specimens distinctly differ from those of Australia (Noro et al., 1994) in having linear leaves, elliptical vesicles, and usually terete receptacles. Sargassum swartzii has some resembling characters with S. binderi and $S$. oligocystum. However, S. swartizii is distinguished easily by its linear leaves and cymosely arranged receptacles with few spines near the tips. This species is a new record for Thailand.

Acknowledgements. We are deeply indebted to Professor Khanjanapaj Lewmanomont for reading and improving the manuscript. Our thanks go to the Institute of Marine Science, Burapha University; the Faculty of Fisheries, Kasetsart University; Graduate School of Agriculture, Kyoto University and School of Fisheries Science, Kitasato University. This study was supported by the JSPS Multilateral Core University Program on Coastal Marine Science, Japan. 


\section{REFERENCES}

Agardh, C.A. 1820. Species algarum, vol.1, iv +168pp. Berling, Lund.

Agardh, C.A. 1824. Systema algarum, xxxviii + 312 pp. Berling, Lund.

Agardh, J.G.. 1848. Species genera et ordines algarum 1. Species, genera of ordines fucodearum ... I.viii + 363pp. Gleerup, Lund.

Agardh, J.G.. 1889. Species Sargassorum australiae descriptae et dispositate. Kgl. Svenska Vet.-Acad. Handl. 23: 1-133, pls. 1-31.

Ajisaka, T. 2002. Sargassum specimens from Singapore and Malaysia in the herbarium of the Bishop Museum. In: I.A. Abbott and K. McDermid (eds). Taxonomy of economic seaweeds with reference to some Pacific species vol. 8, California Sea Grant College System: 77-88.

Ajisaka, T. and K. Lewmanomont. 2004. Variations in the basal system and stolons of Sargassum stolonifolium in the Andaman Sea. In: I.A. Abbott and K. McDermid (eds). Taxonomy of economic seaweeds with reference to some Pacific and other locations vol. 9, Hawaii Sea Grant College Program: 57-72.

Ajisaka, T., T. Noro and T. Yoshida. 1995. Zygocarpic Sargassum species (Subgenus Sargassum) from Japan. In: I.A. Abbott (ed). Taxonomy of economic seaweeds with reference to some Pacific species vol. 5, California Sea Grant College System: 11-44.

Ajisaka, T., S.M. Phang and T. Yoshida. 1999. Preliminary report of Sargassum species collected from Malaysian coasts. In: I.A. Abbott (ed). Taxonomy of economic seaweeds with reference to some Pacific species vol. 7, California Sea Grant College System: $23-41$.

Aungtonya, C. and L.M. Liao. 2002. Marine flora (algae and seagrasses) in the reference collection of the Phuket Marine Biological Center, Thailand. Phuket mar. biol. Cent. Res. Bull. 64: 65-80.

Chou, H.N. and Y.M. Chiang. 1981. The Sargassum of Taiwan. Acta Oceanogr. Taiwanica Sci. Rep. Natl. Taiwan Univ. 12: 132-149.

Egerod, L. 1974. Report of the marine algae collected on the fifth Thai-Danish expedition of 1966. Botanica Marina 17: 130-157.

Grunow, A. 1915. Additamena ad cognitionem Sargassorum. K.K. Zool.-Bot. gesell. Verhandl. Vienna $66: 1-48,136-185$.

Lewmanomont, K. 1988. Marine algae of coral reefs of Thailand. Thai Fisheries Gazette 41(6) : 561-568.
Lewmanomont, K. and H. Ogawa. 1995. Common Seaweeds and Seagrasses of Thailand. Faculty of Fisheries, Kasetsart University. 164 pp.

Montagne, C. 1845. Plantae cellulares. In: J.B. Hombron and H. Jacquinot (eds). Voyage ou Pole Sud et dans l'Oceanie sur les corvettes l'Astrolabe et la Zelee ... , Botanique. Vol.1.pp. 67-69. Paris.

Nateewathana, A., P. Tantichodok, S. Busarawich and R. Sirivejabandhu 1981. Marine Organisms in the reference collection. Phuket mar. biol. Cent. Res. Bull. 28: 43-82.

Noro, T., T. Ajisaka and T. Yoshida. 1994. Species of Sargassum subgenus Sargassum (Fucales) with compressed primary branches. In: I.A. Abbott (ed). Taxonomy of economic seaweeds with reference to some Pacific species vol. 4, California Sea Grant College: 23-31.

Pham Hoang Ho. 1967. Contribution a l'atude des algues littorales d'Vietnam 1: le genre Sargassum. Ann. Fac. Sci. Saigon pp. 259-332.

Reinbold, T. 1913. Sargassum. In: A. Weber-van Bosse (ed). Myxophyceae, Chlorophyceae, Phaeophyceae. Siboga Expeditie, Vol.59a, Brill, Leiden, pp. 150-174.

Schmidt, J. 1900-1916. Flora of Koh Chang. Contributions to the Knowledge of the Vegetation in the Gulf of Siam. Bianco Luno, Copenhagen, 444 pp.

Setchell, W.A. 1935. Hong Kong Seaweed. IV. Hong Kong Nat. Suppl. 4: 1-24, pls. 1-17.

Trono, G.C., Jr. 1992. The Genus Sargassum in the Philippines. In: I.A. Abbott (ed). Taxonomy of economic seaweeds with reference to some Pacific and western Atlantic species vol. 3, California Sea Grant College: 43-94.

Trono, G.C., Jr. 1997. Field Guide and Atlas of the Seaweed Resources of the Philippines. Bookmark, Inc. Philippines. 306 pp.

Tseng, C.K. 1983. Common seaweeds of China. $\mathrm{i}-\mathrm{x}+$ 316pp., pls. 1-149, Science Press, Beijing.

Tseng, C.K. and Lu Baoren. 1995a. Studies on the Glomerulate Sargassum of China: II. The species group Swartzia. In: I.A. Abbott (ed). Taxonomy of economic seaweeds with reference to some Pacific species vol. 5, California Sea Grant College System: $75-92$.

Tseng, C.K. and Lu Baoren. 1995b. Studies on the Glomerulate Sargassum of China: III. The species group Binderia. In: I.A. Abbott (ed). Taxonomy of economic seaweeds with reference to some Pacific species vol. 5, California Sea Grant College System: 93-106. 
Tseng, C.K., T. Yoshida and Y.M. Chiang. 1985. East Asiatic species of Sargassum subgenus Bactrophycus J. Agardh (Sargassaceae, Fucales), with keys to the section and species. In: I.A. Abbott and J.N. Norris (eds). Taxonomy of economic seaweeds with reference to some Pacific and Caribbean species, California Sea Grant College Program: 1-14.

Turner, D. 1819. Fuci... 4: 1-153, pls. 197-258, H,N'Creery, London.

Womersley, H.B.S. and A. Bailey 1970. Marine algae of the Solomon Islands. Phil. Trans. R. Soc. London 259B: 257-352.
Yamada, Y. 1925. Studien über die Meeresalgen von der Insel Formosa. 2. Phaeophyceae. Bot. Mag. Tokyo 39: 239-254.

Yamada, Y. 1942. Notes on Sargassum from southern parts of Japan. I and II. J. Jpn. Bot. 18:369-381;503519.

Yoshida, T. 1988. Japanese and Taiwanese species of Sargassum subgenus Sargassum. In: I.A. Abbott (ed). Taxonomy of economic seaweeds with reference to some Pacific and Caribbean species vol. 2, California Sea Grant College Program: 5-21, figs. 1-18. 